\title{
FAKTOR-FAKTOR YANG MEMPENGARUHI ADOPSI TEKNOLOGI INFUS ASAP DI KABUPATEN TIMOR TENGAH SELATAN, NTT- INDONESIA
}

\author{
Yasintha L. Kleden \\ Fakultas Pertanian Universitas Nusa Cendana Kupang \\ Nusa Tenggara Timur \\ Email: sinthakleden@ymail.com
}

\author{
F.X. Wagiman, Sunarru Samsi Hariadi, dan Siwi Indarti \\ Fakultas Pertanian Universitas Gadjah Mada
}

\begin{abstract}
The utilization of Smoke Infusion Technology in corn storage has traditionally been proven to reduce the damage of corn caused by the attack of Sitophilus zeamais up to $20 \%$. However, no matter how good a technollogy is invented, it will be useless without the adoption process by the farmers. The research on the response of the farmers on smoke infusion technology in corn storage has been conducted from August to October 2013 with the objective to reveal the factors affecting the response of the farmers on that technology. This research was conducted on 2 sub-regencies in south timor tengah regency, as the testing site of smoke infusion technology. The number of respondents as much as 100 sample farmers, including 50 farmers from Batu Putih sub-regency and 50 sample farmers from Oenino sub-regency. Variables used to estimate the response of the farmers on smoke infusion technology include: attitude, age, education, size of land, state of land owner,active farmers, risk, the role of agents of social reformers and social leader role. The data is analyzed through the methods of descriptive and multiple regresion analysis. The result of the research shows that the farmers for adoption on TIA is more dominantly influenced by attitude, age, risks and social leader role.
\end{abstract}

Keywords: Smoke infusion technology, Adoption, TTS.

\begin{abstract}
ABSTRAK
Penggunaan Teknologi Infus Asap (TIA) dalam penyimpanan jagung secara tradisional, telah terbukti mampu mengurangi kerusakan jagung mencapai $20 \%$ akibat serangan Sitophilus zeamais. Sebaik apapun teknologi yang dihasilkan akan tidak berguna apabila tidak diadopsi oleh petani. Penelitian tentang adopsi TIA dilaksanakan pada bulan Agustus - Oktober 2013 yang bertujuan untuk mengetahui faktorfaktor yang mempengaruhi adopsi TIA. Penelitian dilaksanakan di 2 kecamatan di Kabupaten Timor Tengah Selatan (TTS) yang merupakan lokasi pengkajian aplikasi TIA. Jumlah responden sebanyak 100 petani dengan rincian Kecamatan Batu Putih 50 petani dan Kecamatan Oenino 50 petani. Variabel yang digunakan untuk mengestimasi respon petani mengadopsi TIA adalah sikap, umur, pendidikan, luas lahan, status kepemilikan lahan, keaktifan petani, resiko, peran agen pembaharu dan peran pemimpin sosial. Data dianalisis secara deskriptif dan analisis regresi berganda. hasil penelitian menunjukkan bahwa peluang petani untuk mengadopsi TIA lebih dominan dipengaruhi oleh faktor sikap (X1), umur (X2), resiko (X7) dan peran pemimpin sosial (X9).
\end{abstract}

Kata kunci : Teknologi infus asap, Adopsi, TTS. 


\section{PENGANTAR}

Jagung merupakan makanan pokok sebagian besar masyarakat di NTT, terutama masyarakat yang berdiam di daerah pedesaan. Biro Pusat Statistik (BPS) NTT, 2010 menunjukkan bahwa $70 \%$ masyarakat NTT berdiam di daerah pedesaan dan hamper semua keluarga pedesaan mengkonsumsi jagung sebagai pangan utama. Selanjutnya BPS propinsi NTT, menunjukkan bahwa produksi jagung di NTT pada tahun 2010 adalah 653.621 Ton dengan luas panen $244.583 \mathrm{Ha}$ atau rata-rata $2.67 \mathrm{Ton} / \mathrm{Ha}$ ). Produksi jagung di NTT pada tahun 2011 adalah 522.970 Ton Jika dibandingkan dengan produksi jagung pada tahun 2010, ternyata pada tahun 2011 produksi jagung di NTT menurun $\pm 20 \%$.

Kabupaten Timor Tengah Selatan (TTS) termasuk salah satu kabupaten di NTT yang mempunyai produksi jagung tertinggi. Namun, produksi jagung di TTS berfluktuasi. Menurut BPS Kabupaten TTS (2011) produksi jagung di Kabupaten TTS pada 3 tahun terakhir, yaitu tahun 2008, 2009 dan 2010 berturut-turut sebesar 80.289, 110.752 dan 61.571 Ton. Tren produktivitas jagung yang menurun diduga disebabkan karena teknologi budidaya jagung masih sangat sederhana. Sementara itu jagung mengalami penyusutan saat disimpan. Pakan (1997) menyatakan bahwa salah satu penyebab kehilangan jagung saat disimpan adalah serangan hama gudang

Jagung disimpan oleh petani dalam bentuk tongkol yang masih berkelobot. Penanganan pascapanen jagung oleh petani NTT khususnya TTS, sebagai berikut: selama proses penyimpanan (mulai dari awal-akhir masa penyimpanan) petani melakukan pengasapan di tempat penyimpanan jagung untuk mengusir hama gudang. Pengasapan dilakukan dengan membakar daun-daun kering, tongkol jagung, pelepah kelapa, kayu bakar berukuran kecil maupun besar untuk memungkinkan api dapat membara lama (Mudita dkk., 2009). Pengasapan intensif biasanya dilakukan selama 1,5 bulan, selanjutnya pengasapan hanya akan dilakukan pada saat proses kegiatan masakmemasak makanan. Kelemahan cara ini adalah penyebaran asap yang tidak merata karena hanya berkisar dibagian bawah parapara.

Hasil penelitian de Rosari dkk., 2000, menunjukan bahwa tingkat kerusakan jagung pada sistem penanganan pasca panen pola petani di Kabupaten TTS mencapai 30 - $50 \%$. Sedangkan penelitian oleh Pakan (1997), di kabupaten lain di Pulau Timor dengan teknik penanganan pasca panen yang sama, menunjukkan kerusakan jagung $33,35 \%$. Untuk mengatasi masalah tersebut pada tahun 2001 Balai Pengkajian Teknologi Pertanian (BPTP) NTT memperkenalkan sebuah teknologi sederhana yang dikenal dengan nama TIA. Alat ini berfungsi untuk mendistribusi asap dari tungku api ke bagian atas para-para tempat penyimpanan jagung. Teknologi ini berhasil karena mampu menekan kerusakan jagung sebesar 10-20 \% (Murdelelono \& Hosang, 2009).

Sebaik apapun teknologi yang dihasilkan akan percuma saja apabila tidak diadopsi oleh petani. Adopsi dalam proses penyuluhan (pertanian), pada hakikatnya dapat diartikan sebagai proses perubahan perilaku baik yang berupa pengetahuan (cognitive), sikap (affective), maupun keterampilan (psychomotor) pada diri seseorang setelah menerima inovasi yang disampaikan oleh penyuluh. Penerimaan disini mengandung arti tidak sekedar tahu, tetapi sampai benar-benar melaksanakan ataupun menerapkan dengan benar serta menghayatinya dalam kehidupan penerimaan inovasi tersebut, biasanya dapat diamati secara langsung oleh orang lain, sebagai cerminan adanya perubahan sikap, pengetahuan dan keterampilan (Mardikanto, 1993). TIA ini telah disosialisasikan pada tahun 2001. Kenyataannya pada tahun 2009 sampai dengan tahun 2013 petani di TTS tidak lagi menggunakan TIA, bahkan perangkat TIA yang dulu dipasang dalam tempat penyimpanan sudah tidak ada (Kleden, 2013).

Penelitian inibertujuan untukmengidentifikasi faktor-faktor yang mempengaruhi petani untuk mengadopsi TIA, sehingga 
diharapkan dapat mempercepat transfer teknologi pada petani. Parameter yang digunakan untuk mengestimasi faktorfaktor yang mempengaruhi peluang petani dalam mengadopsi TIA adalah sikap, umur, pendidikan, luas lahan, status kepemilikan lahan, keaktifan petani, resiko, peran agen pembaharu, dan peran pemimpin sosial.

Penelitian ini sudah dilakukan pada bulan Agustus-Oktober 2013 di Kabupaten TTS, tepatnya di Kecamatan Batu Putih dan Kecamatan Oenino. Daerah ini dipilih sebagai lokasi penelitian atas pertimbangan karena kedua desa ini merupakan desa yang sudah pernah disuluh tentang TIA, walaupun masih dalam jumlah sedikit (10 KK). Sehingga dengan kategori tersebut dianggap paling mendekati untuk keberhasilan TIA melalui aktivitas pendampingan, pembinaan dan penyuluhan dari instansi terkait atau agen pembaharu. Transportasi dan komunikasi di daerah sasaran lebih lancar dari desa lainnya.

Pengambilan sampel dilakukan secara acak sederhana (simple random sampling). Jumlah responden yang terlibat sebanyak 100 petani. Metode pengumpulan data dilakukan melalui (1) Wawancara adalah proses memperoleh keterangan untuk tujuan penelitian dengan cara tanya jawab sambil bertatap muka antara si penanya atau pewawancara dengan si penjawab atau responden dengan menggunakan alat yang dinamakan interview guide (panduan wawancara) atau kuisioner.(2) Observasi adalah cara pengambilan data dengan menggunakan mata tanpa ada alat pertolongan alat standar lain untuk keperluan tersebut, dan (3) Pencatatan yaitu mencatat sumber-sumber informasi dari pustaka maupun instansi-instansi yang terkait dengan penelitian ini, seperti sejarah dan manfaat TIA.Dalam penelitian ini ada dua jenis data yaitu data primer adalah data yang diperoleh secara langsung dari responden dengan teknik wawancara menggunakan kuisioner, misalnya biodata responden seperti nama, umur, jenis kelamin, pendidikan, luas lahan garapan, status kepemilikan lahan, keaktifan petani dalam mengikuti kegiatan penyuluhan, sikap petani, risiko kegagalan suatu inovasi, peran agen pembaharu, peran pemimpin sosial. Sedangkan data sekunder yaitu, data yang dikumpulkan dari instansi atau lembaga yang berkaitan dengan penelitian yang dilakukan, misalnya monografi lokasi penelitian.

Alat pendukung analisis menggunakan Regresi Linier Berganda yang digunakan untuk mengidentifikasi faktor-faktor yang mempengaruhi petani dalam mengadopsi TIA. Persamaan fungsi regresi berganda sebagai berikut:

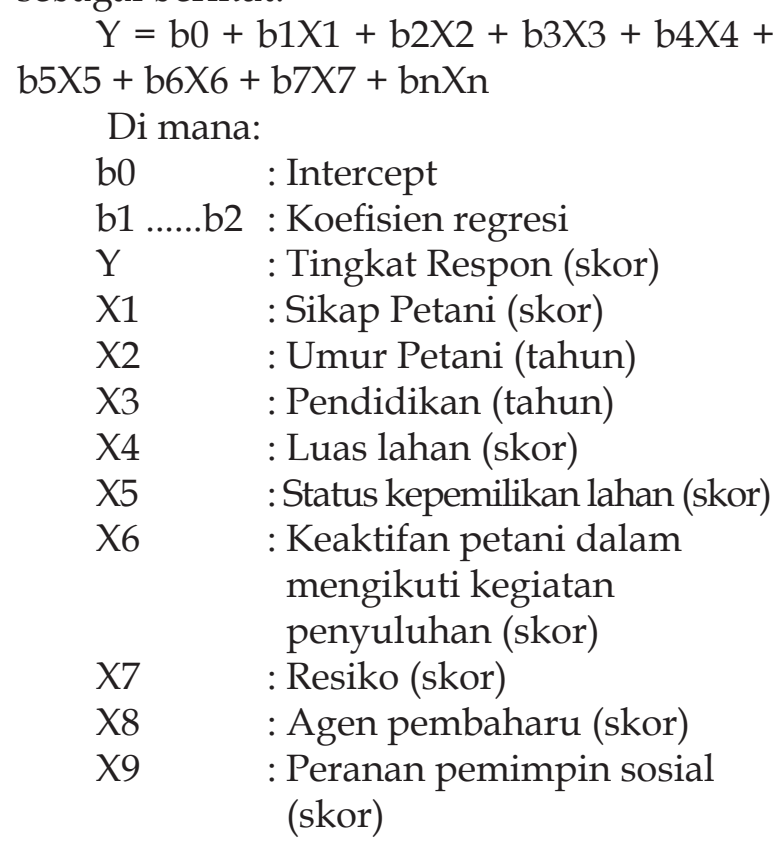

\section{PEMBAHASAN Sikap}

Menurut Azwar (2002) sikap merupakan suatu perasaan yang mendukung atau memihak maupun perasaan yang tidak mendukung atau menolak seseorang terhadap suatu objek. Sikap juga merupakan kecenderungan untuk bertindak ataupun bereaksi terhadap suatu rangsangan. Oleh karena itu, sikap petani dapat didefenisikan sebagai respon petani terhadap suatu teknologi yang diperolehnya, dan pada akhirnya petani tersebut menerima atau menolak teknologi tersebut sehingga dapat mempengaruhi pengetahuan, perasaan, dan tindakan atau perilaku petani. 
Tabel 1 menunjukkan bahwa sikap petani sangat tidak setuju dengan penggunaan TIA sebesar $55 \%$ dan $28 \%$ yang ragu-ragu dengan penggunaan TIA. Hal ini mungkin disebabkan karena sudah lama sekali TIA tidak dipergunakan jadi masyarakat mulai lupa dengan manfaat TIA. Seiring dengan hilangnya informasi tentang TIA ini membuat petani ragu untuk menggunakan TIA sehingga menyebabkan sikap petani semakin tertutup.

Tabel 1. Distribusi Tingkat Sikap Petani terhadap TIA

\begin{tabular}{l|l|l|l}
\hline \multicolumn{1}{c|}{ Skor Sikap Petani } & \multicolumn{1}{c|}{ Kategori Sikap petani } & \multicolumn{1}{c}{ Jumlah Petani } & \multicolumn{1}{c}{$\%$} \\
\hline$\leq 8$ & Sangat Setuju & 0 & 0 \\
\hline $9-17$ & Setuju & 1 & 1 \\
\hline $18-26$ & Ragu-ragu & 26 & 26 \\
\hline $27-33$ & Tidak Setuju & 18 & 18 \\
\hline$\geq 34$ & Sangat Tidak Setuju & 55 & 55 \\
\hline Total $=$ & & 100 & 100 \\
\hline
\end{tabular}

Sumber : Analisis Data Primer, 2014

\section{Umur Petani}

Kemampuan fisik seorang petani dalam melaksanakan kegiatan usaha taninya sangat dipengaruhi oleh tingkat umur. Umumnya semakin tinggi tingkat umur, maka kemampuan untuk bekerja semakin meningkat sampai batas tertentu dan pada batas tertentu pula kemampuannya akan semakin menurun. Umur petani responden berkisar dari 22 sampai 78 tahun (Tabel 2). Mayoritas $83 \%$ berumur produktif selebihnya sebesar $17 \%$ berumur non produktif.

Tabel 2. Sebaran Petani berdasarkan Umur

\begin{tabular}{l|l|l|l|l}
\hline Klasifikasi Umur (Tahun) & $\begin{array}{c}\text { Rerata } \\
\text { Umur }\end{array}$ & \multicolumn{1}{|c|}{ Kategori } & Jumlah Petani (Orang) & $\begin{array}{c}\text { Persentase } \\
(\mathbf{\%})\end{array}$ \\
\hline $22-59$ & 43 & Produktif & 83 & 83 \\
\hline $60-78$ & 68 & Non Produktif & 17 & 17 \\
\hline Total $=$ & & 100 & 100 \\
\hline
\end{tabular}

Sumber : Analisis Data Primer, 2014

\section{Pendidikan}

Pendidikan memegang peranan penting dalam menentukan perubahan sikap petani ketika mereka menerima inovasi baru. Selain itu tingkat pendidikan formal yang dimiliki seseorang merupakan suatu indikasi dalam bertindak secara rasional dan berpola pikir serta daya penalarannya yang baik. Hal ini dapat merubah sikap dan perilakunya dalam melaksanakan kegiatan usaha taninya. Tabel 3 menggambarkan tingkat pendidikan formal petani responden, yang mana sebanyak $20 \%$ petani responden tidak sekolah atau tidak memperoleh pendidikan formal. Dari $80 \%$ yang memperoleh pendidikan formal tersebut, mayoritas 37\% berpendidikan SD, 19\% SMP, 17\% SMA, 3\% Diploma dan 3\% Sarjana.

Tabel 3. Sebaran Petani berdasarkan Pendidikan Formal

\begin{tabular}{l|l|l}
\hline \multicolumn{1}{c}{ Klasifikasi Pendidikan (Tingkat) } & Jumlah Petani (Orang) & Persentase (\%) \\
\hline Tidak Sekolah & 20 & 20 \\
\hline Sekolah Dasar (SD) & 38 & 38 \\
\hline Sekolah Menengah Pertama (SMP) & 19 & 19 \\
\hline Sekolah Menengah Atas (SMA) & 17 & 17 \\
\hline Diploma (D3) & 3 & 3 \\
\hline S1 & 3 & 3 \\
\hline TOTAL & 100 & 100 \\
\hline
\end{tabular}

Sumber : Analisis Data Primer, 2014 


\section{Luas Lahan}

Bagi seorang petani, lahan merupakan salah satu faktor produksi yang sangat penting karena sangat menentukan dalam pengembangan usaha pertaniannya. Mayoritas petani responden, yaitu 57\% memiliki lahan sempit dengan rerata luas $4.359,65 \mathrm{~m}^{2}$. Sebanyak $41 \%$ petani yang memiliki $10.000-30.000 \mathrm{~m}^{2}$ dengan rerata luas $13.302,44 \mathrm{~m}^{2}$. Petani yang memiliki lahan seluas lebih dari $30.000 \mathrm{~m}^{2}$ sebanyak 2\% dengan rerata luas $50.000 \mathrm{~m}^{2}$ (Tabel 4).

Tabel 4. Sebaran Petani berdasarkan Luas Lahan

\begin{tabular}{l|l|l|l|l}
\hline \multicolumn{2}{c|}{ Luas Lahan $\left(\mathbf{M}^{2}\right)$} & \multirow{2}{*}{ Kategori Lahan } & \multicolumn{1}{|c|}{$\begin{array}{c}\text { Jumlah Petani } \\
\text { (Orang) }\end{array}$} & $\begin{array}{c}\text { Persentase } \\
(\%)\end{array}$ \\
\hline$<10.000$ & \multicolumn{1}{c}{ Rerata Luas Lahan } & & 57 & 57 \\
\hline $10.000-30.000$ & $4.359,65$ & Sempit & 57 & 41 \\
\hline$>30.000$ & $13.302,44$ & Sedang & 41 & 2 \\
\hline Total $=$ & 50.000 & Luas & 2 & 100 \\
\hline
\end{tabular}

Sumber : Analisis Data Primer, 2014

\section{Status Kepemilikan}

Status kepemilikan lahan menentukan juga pengembangan pertanian di suatu daerah. Status pemilikan lahan antara lain milik sendiri dan sakap (bagi hasil). Lahan milik sendiri akan menyebabkan petani lebih serius dalam pengembangan lahan secara intensif. Status lahan yang dimiliki petani responden disajikan dalam tabel 5 . Sebanyak $83 \%$ petani yang status kepemilikkan lahannya adalah milik sendiri. Kondisi ini sangat baik bahwa petani yang umumnya mempunyai otoritas yang kuat untuk mengelola lahan pertaniannya. Petani yang menyakap atau mengolah lahan milik orang lain dengan sistem bagi hasil sebanyak $17 \%$.

Tabel 5. Sebaran Petani berdasarkan Status Kepemilikan Lahan

\begin{tabular}{l|l|l}
\hline $\begin{array}{c}\text { Status } \\
\text { Kepemilikan }\end{array}$ & $\begin{array}{l}\text { Jumlah Petani } \\
\text { (Orang) }\end{array}$ & $\begin{array}{c}\text { Persentase } \\
(\mathbf{\%})\end{array}$ \\
\hline Sadap & 17 & 17 \\
\hline Milik Sendiri & 83 & 83 \\
\hline Total $=$ & 100 & 100 \\
\hline
\end{tabular}

\section{Keaktifan Petani}

Tabel 6 menunjukkan bahwa mayoritas petani responden keaktifannya dalam mengikuti kegiatan penyuluhan sudah cukup aktif. Kondisi ini sebenarnya kurang mendukung program pembangunan pertanian, maka untuk meningkatkan keaktifan petani, mereka perlu dimotivasi dengan cara melibatkan petani pada setiap kegiatan penyuluhan dan materi penyuluhan harus memberikan informasi-informasi yang menarik seperti selalu memperkenalkan teknologi pertanian terbaru, cara mencegah dan mengendalikan hama dan penyakit tanaman, varietas baru yang tahan terhadap hama dan penyakit, dan juga informasi pertanian lainnya. Informasi dari penyuluh yang menarik dan selalu terbaru diyakini akan memotivasi petani untuk mencaritahu lebih banyak lagi sehingga petani akan termotivasi untuk menghadiri setiap kegiatan penyuluhan.

Sumber : Analisis Data Primer, 2014

Tabel 6. Distribusi Tingkat Keaktifan Petani Mengikuti Kegiatan Penyuluhan

\begin{tabular}{l|l|l|l}
\hline \multicolumn{1}{c|}{ Skor } & \multicolumn{1}{c|}{$\begin{array}{c}\text { Kategori } \\
\text { Keaktifan Petani }\end{array}$} & Jumlah Petani (Orang) & \multicolumn{1}{c}{ Persentase (\%) } \\
\hline$\leq 10$ & Sangat aktif & 22 & 22 \\
\hline $11-20$ & Aktif & 13 & 13 \\
\hline $21-30$ & Cukup aktif & 29 & 29 \\
\hline $31-40$ & Kurang Aktif & 27 & 27 \\
\hline$\geq 41$ & Tidak Aktif & 9 & 9 \\
\hline \multicolumn{2}{l}{ Total $=$} & 100 & 100 \\
\hline
\end{tabular}

Sumber : Analisis Data Primer, 2014 


\section{Risiko}

Resiko dalam penelitian ini adalah kegagalan dalam menerapkan TIA. Tingkat risiko yang ditanggung mempengaruhi keputusan masyarakat dalam menerapkan suatu teknologi baru. Bagi masyarakat di pedesaan, adopsi suatu teknologi baru relatif lambat karena karakteristiknya yang no risk dan safety first (Satria, 2002). Oleh karena itu, keberanian petani dalam menanggung risiko gagal akibat menggunakan inovasi baru, merupakan faktor yang diduga mempengaruhi adopsi inovasi. Distribusi tingkat resiko kegagalan TIA disajikan dalam tabel 7, menjelaskan bahwa tingkat resiko kegagalan TIA sangat rendah yaitu sebesar $37 \%$. Dari data ini bahwa semakin rendah resiko kegagalan TIA maka semakin tinggi petani yang mau mengadopsi inovasi tersebut.

Tabel 7. Distribusi Tingkat Resiko Kegalalan TIA

\begin{tabular}{l|l|l|l}
\hline \multicolumn{1}{c|}{ Skor } & \multicolumn{1}{c|}{ Kategori Resiko } & Jumlah Petani (Orang) & \multicolumn{1}{c}{ Persentase (\%) } \\
\hline$\leq 9$ & Sangat Tinggi & 1 & 1 \\
\hline $10-19$ & Tinggi & 11 & 11 \\
\hline $20-29$ & Sedang & 16 & 16 \\
\hline $30-39$ & Rendah & 35 & 35 \\
\hline$\geq 40$ & Sangat Rendah & 37 & 37 \\
\hline Total $=$ & 100 & 100 \\
\hline
\end{tabular}

Sumber : Analisis Data Primer, 2014

\section{Peran Agen Pembaharu}

Tabel 8 menjelaskan bahwa 31\% petani yang mengatakan bahwa agen pembaharu sering melakukan kunjungan dan kegiatan penyuluhan. Sedangkan 30\% petani responden mengatakan kadangkadang. Dari data ini dapat disimpulkan bahwa kehadiran penyuluh belum terlalu dirasakan manfaatnya karena dinilai kurang memberikan informasi yang baru tentang pertanian. Hal ini akan mengakibatkan petani tidak termotivasi untuk mengikuti kegiatan penyuluhan.

Tabel 8. Distribusi Tingkat Peran Agen Pembaharu

\begin{tabular}{l|l|l|l}
\hline \multicolumn{1}{c|}{ Skor } & \multicolumn{1}{c|}{$\begin{array}{c}\text { Kategori Peran Agen } \\
\text { Pembaharu }\end{array}$} & Jumlah Petani (Orang) & \multicolumn{1}{c}{$\begin{array}{c}\text { Persentase } \\
(\%)\end{array}$} \\
\hline$\leq 8$ & Sangat Sering & 17 & 17 \\
\hline $9-17$ & Sering & 31 & 31 \\
\hline $18-26$ & Kadang-kadang & 30 & 30 \\
\hline $27-35$ & Jarang & 16 & 16 \\
\hline$\geq 36$ & Tidak Pernah & 6 & 6 \\
\hline Total $=$ & 100 & 100 \\
\hline
\end{tabular}

Sumber : Analisis Data Primer, 2014

\section{Peran Pemimpin Sosial}

Tabel 9 menjelaskan bahwa menurut petani yaitu sebesar 30\% peran pemimpin sosial termasuk kategori kadang-kadang, karena keterlibatan pemimpin sosial dalam

suatu kegiatan hanya terjadi jika ada kepentingan tersendiri dengan lembaga yang datang membawa informasi baru untuk pembangunan pertanian di daerah mereka.

Tabe19. Distribusi Tingkat Peran Pemimpin Sosial

\begin{tabular}{l|l|l|l}
\hline \multicolumn{1}{c|}{ Skor } & Kategori Peran Pemimpin Sosial & Jumlah Petani (Orang) & Persentase (\%) \\
\hline$\leq 9$ & Sangat Sering & 12 & 12 \\
\hline $10-19$ & Sering & 28 & 28 \\
\hline $20-29$ & Kadang-kadang & 30 & 30 \\
\hline $30-39$ & Jarang & 25 & 25 \\
\hline
\end{tabular}




\begin{tabular}{l|l|l|l}
\hline \multicolumn{1}{c|}{ Skor } & Kategori Peran Pemimpin Sosial & Jumlah Petani (Orang) & Persentase (\%) \\
\hline$\geq 40$ & Tidak Pernah & 5 & 5 \\
\hline Total $=$ & 100 & 100 \\
\hline
\end{tabular}

Sumber : Analisis Data Primer, 2014

\section{Analisis Linier Berganda (Peluang Petani dalam Mengadopsi TIA /Y)}

Dalam penelitian ini, yang dikenal sebagai variabel dependent adalah peluang adopsi TIA (Y) sedangkan yang bertindak sebagai variabel independent $(X)$ adalah umur, pendidikan, luas lahan, status kepemilikan, sikap, resiko, keaktifan petani, peran agen pembaharu, dan peran pemimpin sosial.

Tabel 10. Hasil Analisis Regresi Logit Faktor-faktor yang Mempengaruhi Adopsi TIA

\begin{tabular}{l|l|l|l|l}
\hline \multicolumn{1}{c|}{ Variabel } & \multicolumn{1}{c|}{ Koefisien } & \multicolumn{1}{c|}{ Nilai t } & \multicolumn{1}{c}{ Sig. } & \multicolumn{1}{c}{ Keterangan } \\
\hline Konstanta & 19,662 & 4,561 & 0,000 & Signifikan \\
\hline Sikap (X1) & 0,314 & 3,227 & 0,002 & Signifikan \\
\hline Umur (X2) & $-0,194$ & $(-) 2,311$ & 0,023 & Signifikan \\
\hline Pendidikan (X3) & 0,087 & 1,018 & 0,311 & Tidak signifikan \\
\hline Luas Lahan (X4) & $-0,137$ & $(-) 1,686$ & 0,095 & Tidak signifikan \\
\hline Status Kepemilikan (X5) & $-0,068$ & $(-) 0,855$ & 0,395 & Tidak signifikan \\
\hline Keaktifan (X6) & 0,125 & 1,044 & 0,299 & Tidak signifikan \\
\hline Resiko (X7) & $-0,215$ & $(-) 2,351$ & 0,021 & Signifikan \\
\hline Peran Agen Pembaharu (X8) & 0,064 & 0,632 & 0,529 & Tidak signifikan \\
\hline Peran Pemimpin Sosial (X9) & 0,237 & 2,211 & 0,030 & Signifikan \\
\hline
\end{tabular}

Sumber : Analisis Data Primer, 2014

Berdasarkan hasil uji statistik dengan analisis regresi berganda, maka persamaaan regresi linier berganda sebagai berikut:

$Y=19,662+0,314$ X1-0,194X2-0,215X7 + $0,237 \times 9$

Tingkat signifikansi (a) yang digunakan sebesar $5 \%$ dan dibandingkan dengan tingkat signifikansi masing-masing variabel independen. Apabila tingkat signifikan independen tersebut $<0,05$, maka variabel independen tersebut berpengaruh signifikan terhadap variabel dependennya pada level $5 \%$, dan sebaliknya apabila tingkat signifikan independen tersebut $>0,05$, maka variabel independen tersebut tidak berpengaruh signifikan terhadap variabel dependennya pada level 5\%.

Pada Tabel 10 terlihat bahwa nilai konstanta 19,662 dan secara statistik sangat nyata $(\mathrm{P}<0,05)$. Hal ini berarti bahwa tanpa memperhatikan variabel sikap, umur, pendidikan, luas lahan, status kepemilikan, keaktifan petani, risiko, peranagen pembaharu, dan peran pemimpin sosial maka peluang petani yang mengadopsi TIA sebanyak 20 orang. Pada tabel 10 terdapatempat peubah bebas yaitu umur, luas lahan, status kepemilikan dan resiko bertanda negatif. Tanda negatif (-) yang terdapat pada nilai koefisien dan t-hitung tersebut menunjukkkan bahwa hubungannya berbanding terbalik. Variabel sikap, pendidikan, keaktifan petani, peran agen pembaharu dan peran pemimpin sosial bertanda positif.

\section{Faktor-Faktor yang Mempengaruhi Adopsi TIA}

Tahap adopsi tidak selamanya berakhir dengan penerimaan secara penuh dan terus menerus tetapi bisa juga berakhir penolakan. Tahapan tersebut tidak selamanya berurutan, tetapi dapat terjadi peloncatan pada setiap tahapan. Proses tersebut biasanya tidak berakhir dengan adopsi tetapi berlanjut ke konfirmasi sebagai pengukuhan menjadi 4 tahap, yaituPertama, pengenalan atau reaksi yang muncul dari dalam diri petani untuk mengenal ide baru tersebut sesuai dengan apa 
yang didengar atau diketahui dari berbagai sumber informasi yang ada, sehingga tahap ini memberikan indikasi bahwa petani bersangkutan telah memiliki kesadaran atau berminat untuk melakukan suatu ide baru. Kedua, tahap persuasi yaitu suatu sikap yang muncul dalam diri petani untuk menyetujui atau tidak terhadap suatu ide baru. Pada tahap ini didominasi dengan penilaian manfaat yang dapat didapatkan dalam melaksanakan ide baru tersebut. Sehingga apabila manfaat yang diperoleh lebih besar, maka petani dapat menyetujui adanya suatu ide baru. Dengan demikian petani dalam tahap ini memberikan indikasi bahwa telah ada penilaiannya terhadap penggunaan TIA dalam tempat penyimpanan jagung (rumah bulat). Ketiga, tahap keputusan yaitu suatu langkah penentu dalam penentuan terhadap berbagai alternatif yang ada. Pada tahap ini, petani dihadapkan pada pilihan menolak atau menerima, setuju atau tidak setuju terhadap ide baru tersebut. Tahap ini memberikan indikasi dalam bentuk mencoba akan adanya suatu ide baru. Keempat, tahap konfirmasi,yaitu upaya petani untuk mencari keterangan-keterangan lebih jauh sehubungan dengan ide baru yang telah diketahui, guna memperkuat hasil keputusannya dalam menerima ide baru tersebut; sehingga tahap ini merupakan yang terakhir dalam penerimaan atau mengadopsi ide baru tersebut.

Berdasarkan uraian di atas, maka penggunaan TIA dalam tempat penyimpanan jagung secara tradisional yang ada di Kabupaten TTS, termasuk suatu paket inovasi baru, sehingga mengakibatkan kecenderungan potensial untuk beraksi pada stimulus. Adanya reaksi dari petani akan menghendaki sejauhmana peluang petani mengadopsi TIA karena kenyataannya untuk mengadopsi TIA dapat dipengaruhi oleh berbagai faktor, baik faktor dari luar (eksternal) maupun dari dalam (internal).

Sikap (X1) memiliki hubungan positif dengan peluang petani dalam mengadopsi TIA dan secara statistik berpengaruh nyata $(\mathrm{P}<0,05)$, artinya semakin terbuka (positif) sikap petani terhadap suatu inovasi baru, maka semakin tinggi peluang petani mengadopsi TIA. Kebanyakan petani kecil agak lamban dalam mengubah sikapnya terhadap perubahan. Menurut Walgito, 1999 sikap mengandung tiga komponen yang membentuk struktur sikap. Pertama, komponen kognitif (komponen perseptual), yaitu komponen yang berkaitan dengan pengetahuan, pandangan, keyakinan merupakan hal-hal yang berhubungan dengan bagaimana orang mempersepsi terhadap objek sikap. Kedua, komponen afektif (komponen emosional), yaitu komponen yang berhubungan dengan rasa senang atau tidak senang terhadap objek sikap. Rasa senang merupakan hal yang positif, sedangkan rasa tidak senang merupakan hal yang negatif. Ketiga, komponen konatif (komponen prilaku atau action component), yaitu komponen yang berhubungan dengan kecenderungan bertindak terhadap objek sikap. Komponen ini menunjukan intensitas sikap, yaitu menunjukkan besar kecilnya kecenderungan bertindak atau berperilaku seseorang terhadap sikap objek. Hubungan antara sikap, niat, dan perilaku adalah bahwa sikap terlebih dahulu mempengaruhi niat, kemudian mempengaruhi perilaku. Secara sederhana teori tindakan beralasan mengatakan bahwa seseorang akan melakukan suatu perbuatan apabila ia memandang perbuatan itu positif dan bila ia percaya bahwa orang lain ingin agar ia melakukannya.

Umur (X2) memiliki hubungan yang negatif dengan peluang responden mengadopsi TIA yang secara statistik berpengaruh nyata $(\mathrm{P}<0,05)$. Semakin muda umur responden, semakin tanggap terhadap inovasi baru sehingga semakin tinggi peluang petani untuk mengadopsi TIA, sedangkan yang lebih tua pada umumnya bertahan pada sistem yang lama yang sudah biasa diterapkan oleh masyarakat. Sebagaimana pendapat Soekartawi (1988) bahwa makin muda petani biasanya mempunyai semangat untuk ingin tahu apa yang belum mereka ketahui, sehingga dengan demikian mereka berusaha untuk lebih cepat melakukan 
adopsi inovasi walaupun sebenarnya mereka masih belum berpengalaman dalam soal adopsi inovasi tersebut.

Hubungan pendidikan (X3) dan adopsi TIA positif dan secara statistik berpengaruh tidak nyata $(\mathrm{P}>0,05)$. Pendidikan formal maupun informal memegang peranan penting dalam menentukan perubahan sikap pada petani. Tingkat pendidikan formal yang dimiliki seseorang merupakan suatu indikasi dalam bertindak secara rasional, sedang pendidikan informal akan lebih berpengaruh dalam upaya meningkatkan peluang petani dalam mengadopsi suatu teknologi baru. Dalam usaha tani di daerah ini pada umumnya mempunyai pendidikan formal yang masih rendah, dan upaya pengendalian hama gudang yang dilakukan masih bersifat turun temurun dan masih menggunakan teknologi yang sederhana atau masih bersifat tradisional. Kemampuan petani dalam upaya pengendalian hama gudang yang masih terbatas menjadi salah satu faktor utama rendahnya peluang adopsi TIA. pendidikan informal seperti pelatihanpelatihan singkat tentang manfaat TIA dan pembuatan TIA, penyuluhan-penyuluhan akan sangat efektif bagi peningkatan peluang adopsi TIA. Meskipun tingkat pendidikan formalnya rendah (hanya sampai SD) apabila sering mengikuti pelatihan-pelatihan dan penyuluhan tentang TIA akan lebih berhasil dibandingkan pendidikan yang tinggi dengan kemampuan usaha tani dan pengalaman yang rendah ataupun hanya pas-pasan. Pendidikan informal sangat berpengaruh dalam upaya meningkatkan peluan petani mengadopsi TIA.

Luas lahan (X4) berhubungan negatif dengan peluang responden mengadopsi TIA dan secara statistik berpengaruh tidak nyata $(\mathrm{P}>0,05)$ yang berarti bahwa semakin luas lahan garapan seseorang semakin rendah peluang responden mengadopsi TIA. Kesimpulan ini dari segi teori maupun intuitif tidak konsisten, karena semakin luas usaha tani seseorang pada umumnya semakin cepat mengadopsi inovasi, karena memiliki kemampuan ekonomi yang lebih baik. Akan tetapi, untuk mengadopsi TIA kemungkinan teori ini tidak berlaku, karena masalah utama pada adopsi TIA adalah produksi yang dihasilkan harus tinggi. Semakin luas lahan yang dimiliki oleh seseorang belum menjamin produksi jagung yang dihasilkan pun tinggi, sehingga luas sempitnya lahan yang dimiliki oleh seseorang tidak menjamin memiliki peluang yang tinggi untuk mengadopsi TIA.

Hubungan status kepemilikan lahan (X5) dengan peluang petani dalam mengadopsi TIA negatif dan secara statistik berpengaruh tidak nyata $(p>0,05)$. Hal ini berarti bahwa lahan dengan status milik sendiri tidak selalu menjamin lebih mudah menerima suatu inovasi baru. Hasil penelitian ini membuktikan bahwa lahan dengan status sakap ternyata lebih berpeluang dalam mengadopsi inovasi baru karena petani yang hanya mengolah lahan milik orang lain melihat adanya peluang secara ekonomi dari TIA selain itu juga biasanya petani yang mengolah lahan orang lain ini memiliki perjanjian bagi hasil panen.

Keaktifan petani (X6) dalam mengikuti kegiatan penyuluhan berhubungan positif dengan peluang petani dalam mengadopsi TIA dan secara statistik berpengaruh tidak nyata $(p>0,05)$ yang artinya semakin aktif petani mengikuti kegiatan penyuluhan semakin tinggi peluang petani mengadopsi TIA. Selain memperoleh informasi yang terbaru, petani dapat menjalin relasi dengan banyak orang dan bertukar pikiran. Hal ini akan membuat sikap petani semakin terbuka dengan inovasi baru dan peluang untuk mengadopsi inovasi baru pun semakin tinggi,

Risiko (X7) berhubungan negatif dengan peluang responden mengadopsi TIA dan secara statistik tidak nyata $(\mathrm{P}>0,05)$ yang berarti bahwa semakin rendah resiko dari TIA maka semakin tinggi peluang responden mengadopsi TIA.Tingkat risiko yang ditanggung mempengaruhi keputusan masyarakat dalam menerapkan inovasi. Bagi masyarakat di pedesaan, adopsi inovasi relatif lambat karena karakteristiknya yang no risk dan safety first (Satria, 2002). Oleh karena 
itu, keberanian petani dalam menanggung risiko gagal akibat menggunakan inovasi baru, merupakan faktor yang diduga mempengaruhi adopsi inovasi.

Peran agen pembaharu (X8) berhubungan positif dengan peluang responden mengadopsi TIA dan secara statistik tidak nyata $(P>0,05)$ yang berarti bahwa semakin besar peran agen pembaharu semakin tinggi peluang responden mengadopsi TIA. Peran agen pembaharu sebagai faktor luar akan menentukan dalam memberikan pengembangan pengetahuan tentang dunia pertanian dan teknologi yang mengiringinya.

Peran pemimpin sosial (X9) berhubungan negatif dengan peluang responden mengadopsi TIA dan secara statistik nyata $(\mathrm{P}<0,05)$ yang berarti bahwa semakin besar peran pemimpin sosial semakin tinggi peluang responden mengadopsi TIA. Peran pemimpin sosial sangat menetukan arah kebijakan terutama dalam pengembangan pertanian di daerahnya.

\section{SIMPULAN}

Faktor-faktor yang mempengaruhi adopsi TIA dan secara statistik berpengaruh nyata pada taraf $5 \%$ adalah sikap, umur, resiko, dan peran pemimpin sosial. Sedangkan secara statistik yang tidak berpengaruh nyata adalah pendidikan, luas lahan, status kepemilikan, keaktifan petani, dan peran agen pembaharu. Selanjutnya sikap, pendidikan, keaktifan petani, peran agen pembaharu dan peran pemimpin sosial berkorelasi positif terhadap peluang petani dalam mengadopsi TIA, sedangkan umur, luas lahan, status kepemilikan dan resiko berkorelasi negatif terhadap peluang petani dalam mengadopsi TIA.

Untuk memotivasi petani agar mau menerapkan suatu teknologi secara berkelanjutan, maka perlu dilakukan pendekatan partisipatif yang dilaksanakan pada awal pengkajian introduksi teknologi. Pendekatan ini diharapkan akan mempengaruhi partisipasi petani dalam melaksanakan pengkajian secara sukarela, sehingga tingkat adopsi teknologi maupun peluang melanjutkan suatu teknologi di harapkan akan meningkat dan berkelanjutan.

\section{DAFTAR PUSTAKA}

Azwar, S. 2002. Sikap Manusia dan Teori Pengukurannya. Pustaka Pelajar. Yogyakarta.

BPS Propinsi NTT. 2010. Indikator Kesejahteraan Masyarakat NTT. Kupang.

BPS Propinsi NTT. 2011. Indikator Kesejahteraan Masyarakat NTT. Kupang.

BPS Kabupaten TTS. 2011. Timor Tengah Selatan dalam Angka. Kupang.

de Rosari Bernard, Charles Bora, A. Bamualim. 2000. Manajemen Pasca Panen Jagung di NTT. Laporan Tahun I Kerja Sama BPTP NTT dengan Winrock International - On Farm. Kupang.

Kleden Y.L., 2003. Pengaruh penggunaan Teknologi Infus Asap dan Teknik Penyimpanan Jagung terhadap Kerusakan Jagung Akibat Serangan Sitphilus zeamais. Skripsi S1. Universitas Nusa Cendana,Kupang.

Kleden Y.L., 2013. Hama Gudang dan Masalahnya Dalam Tempat Penyimpanan Jagung Secara Tradisional Serta Upaya Pengendalian Yang Dilakukan Petani Di Kecamatan Oenino, Kabupaten Timor Tengah Selatan-Nusa Tenggara Timur. Makalah Masalah Khusus Ilmu Hama Tumbuhan. Fakultas Pertanian - Universitas Gadjah Mada. Yogyakarta.

Mardikanto, T. 1993. Penyuluhan Pembangunan Pertanian. Sebelas Maret University Press. Solo.

Mudita, I W., Utma Aspatria dan M.T. Surayasa. 2009. Pengembangan Model Pengelolaan Ketahanan Hayati Penyimpanan Jagung Berbasis Masyarakat untuk Meningkatkan Ketahanan Pangan di Wilayah Beriklim Kering. Laporan Akhir Tahun I Hibah Kompetitif 
Penelitian Sesuai Prioritas Nasional dengan Tema Ketahanan Pangan. Universitas Nusa Cendana, Kupang.

Murdolelono B., dan E. Hosang, 2009. Effect of Strage Techniques on Quality of Maize seeds of Lamuru and Local Varieties in East Nusa Tenggara. Indonesian Journal of Agriculture 2(2) : 93 - 102.

Pakan, S. 1997. Hama Pascapanen Jagung di Kabupaten Kupang. Buletin
Leguminosae Volume 4 Nomor 1. Undana, Kupang.

Satria, Arif. 2002. Pengantar Sosiologi Masyarakat Pesisir. Pustaka Cidesindo. Jakarta.

Soekartawi. 1988. Prinsip Dasar Komunikasi Pertanian. Penerbit Universitas Indonesia (UI-Press). Jakarta.

Walgito, B. 1999. Sikap, Perilaku, dan Perubahannya. Yogyakarta: Diktat Kuliah (Unpublished). 